\title{
Synthesis, DNA-Binding Activity and Cytotoxicity of Carbamate Derivatives of Hoechst 33258 in Breast Cancer MCF-7 Cells
}

\author{
Krzysztof BielawsKi, ${ }^{*}, a$ Anna BielawsKa, ${ }^{a}$ and Sławomir WolCZYŃSKI ${ }^{b}$ \\ ${ }^{a}$ Department of Medicinal Chemistry and Drug Technology, Medical Academy of Bialystok; Mickiewicza 2, 15-230 \\ Bialystok, Poland: and ${ }^{b}$ Department of Gynecological Endocrinology, Medical Academy of Bialystok; Sklodowskiej 24A, \\ 15-276 Bialystok, Poland. Received January 28, 2002; accepted April 1, 2002
}

\begin{abstract}
A series of carbamate derivatives of Hoechst 33258 was prepared as potential anticancer agents. These new compounds (1-4) were readily prepared in good yields by addition of chloroethyl, bromoethyl, chloropropyl or 4-(chloromethyl)phenyl isocyanates to Hoechst 33258. Their cytotoxic activity was evaluated on human breast cancer MCF-7. Compounds $1-4$ were more cytotoxic than Hoechst 33258. In particular derivative 4 , the most active of the series, is up to 3 times more potent than Hoechst 33258. The DNA-binding ability of these compounds was evaluated by an ultrafiltration method using calf thymus DNA. These data show that in broad terms the cytotoxic potency of $1-4$ in cultured breast cancer MCF-7 cells increases, in accord with their increases in DNA affinity, as shown by the binding constant values.
\end{abstract}

Key words Hoechst 33258; DNA-binding; ultrafiltration assay; breast cancer MCF-7 cell

Hoechst 33258, distamycin, and netropsin are among a number of compounds that bind in the minor groove of DNA and exhibit various degree of antitumour activity. ${ }^{1,2)}$ Several high resolution crystal and NMR structures have been determined for these ligands bound to short oligonucleotides and provide valuable insights into the details of their interaction. ${ }^{3,4)}$ The Hoechst 33258 is bound in the minor groove, with the planar benzimidazole groups oriented parallel to the groove direction and each inner-facing nitrogen atom hydrogen bonding in a bifurcated manner to a pair of adjacent hydrogen bond donors on the edge of the AT base pairs of DNA. ${ }^{3,4)}$ The structure of the bound drug shows that the bulky piperazine ring is located in a GC region, with the minor groove observed to be wider at this sequence. ${ }^{3)}$ The spectroscopic characteristics of Hoechst 33258 family of ligands have brought them into wide use as DNA fluorophores, ${ }^{5)}$ but several have also shown potent activity against a number of microorganisms that lead to AIDS-related opportunistic infections, ${ }^{6}$ as well as exhibiting cytotoxic activity. $^{7-10)}$ In the course of our investigations of minor groove binding drugs, we reported a cytotoxicity and DNA-binding ability of carbamate derivatives of Hoechst 33258 with chloroalkyl and bromoalkyl moieties (Fig. 1).

\section{CHEMISTRY}

Melting points were determined on Buchi 535 meltingpoint apparatus and were uncorrected. Analyses were performed on a Perkin Elmer 2400 analyser. ${ }^{1} \mathrm{H}$-NMR (200 $\mathrm{MHz})$ and ${ }^{13} \mathrm{C}-\mathrm{NMR}(150 \mathrm{MHz})$ spectra were recorded on a Bruker AC 200F spectrometer, using tetramethylsilane (TMS) as an internal standard. Hoechst 33258, DMF, $N, N$-diisopropylethylamine, 2-chloroethyl isocyanate, 2-bromoethyl isocyanate, 3-chloropropyl isocyanate and 4-(chloromethyl)phenyl isocyanate were purchased from Sigma.

Synthesis of Carbamate Derivatives of Hoechst 33258 Hoechst $33258(10 \mathrm{mmol})$ was dissolved in $30 \mathrm{ml}$ of anhydrous $N, N$-dimethylformamide (DMF). $N, N$-diisopropylethylamine $(5.2 \mathrm{ml})$ and appropriate isocyanate $(18 \mathrm{mmol})$ were added slowly. The reaction mixture was stirred for $48 \mathrm{~h}$ at ambient temperature and concentrated under reduced pres- sure. The resulting oil was purified by column chromatography over $\mathrm{Al}_{2} \mathrm{O}_{3}$ (III grade) $(1: 1 \mathrm{MeOH}$ : EtOAc solvent linearly changing to $100 \% \mathrm{MeOH}$ ). The powder obtained on solvent removal was further purified by preparative TLC (silica gel plates, $1: 1 \mathrm{MeOH}: \mathrm{EtOAc}$ ) to give the product as a yellow powder. The product was converted into the salt by taking up in $5 \mathrm{ml}$ of methanol, treated with $3 \mathrm{ml}$ of $2 \mathrm{M} \mathrm{HCl}$ and stirred for $15 \mathrm{~min}$. The trihydrochloride salt was crystallized from $96 \%$ ethanol.

2-[2-(4-((2-Chloroethyl)carbamoyloxy)phenyl)-6-benzimidazolyl]-6-(1-methyl-4-piperazinyl)benzimidazole Trihydrochloride (1): Yield $=43 \%, \quad \mathrm{mp}>300^{\circ} \mathrm{C} .{ }^{1} \mathrm{H}-\mathrm{NMR}$ $\left(\mathrm{DMSO}-d_{6}\right) \delta: 2.65\left(\mathrm{~s}, 3 \mathrm{H}, \mathrm{N}-\mathrm{CH}_{3}\right), 2.80\left(\mathrm{~m}, 4 \mathrm{H}, \mathrm{N}-\mathrm{CH}_{2}-\right)$, $3.24\left(\mathrm{t}, 2 \mathrm{H}, \mathrm{N}-\mathrm{CH}_{2}-, J=6.2 \mathrm{~Hz}\right), 3.38\left(\mathrm{~m}, 4 \mathrm{H}, \mathrm{N}-\mathrm{CH}_{2}-\right)$, $3.64\left(\mathrm{t}, 2 \mathrm{H},-\mathrm{CH}_{2}-\mathrm{Cl}, J=6.2 \mathrm{~Hz}\right), 6.95(\mathrm{~d}, 1 \mathrm{H}, \mathrm{Ar}-\mathrm{H}$, $J=8.4 \mathrm{~Hz}), 7.05(\mathrm{~s}, 1 \mathrm{H}, \mathrm{Ar}-\mathrm{H}), 7.45(\mathrm{~d}, 1 \mathrm{H}, \mathrm{Ar}-\mathrm{H}, J=9.0 \mathrm{~Hz})$, $7.71(\mathrm{~d}, 1 \mathrm{H}, \mathrm{Ar}-\mathrm{H}, J=9.2 \mathrm{~Hz}), 7.82$ (d, $2 \mathrm{H}, \mathrm{Ar}-\mathrm{H}, J=8.2 \mathrm{~Hz}$ ), $8.04(\mathrm{~d}, 1 \mathrm{H}, \mathrm{Ar}-\mathrm{H}, J=8.7 \mathrm{~Hz}), 8.19$ (d, $2 \mathrm{H}, \mathrm{Ar}-\mathrm{H}, J=9.4 \mathrm{~Hz}$ ), $8.38(\mathrm{~s}, 1 \mathrm{H}, \mathrm{Ar}-\mathrm{H}) .{ }^{13} \mathrm{C}-\mathrm{NMR}$ (DMSO- $\left.d_{6}\right) \delta: 41.4\left(\mathrm{~N}-\mathrm{CH}_{3}\right)$, $46.3\left(\mathrm{CH}_{2}-\mathrm{Cl}\right), 47.4\left(\mathrm{~N}-\mathrm{CH}_{2}-\right), 53.5\left(\mathrm{~N}-\mathrm{CH}_{2}-\right), 102.5(\mathrm{Ar})$, $116.7(\mathrm{Ar}), 116.9(\mathrm{Ar}), 123.2(\mathrm{Ar}), 126.4(\mathrm{Ar}), 128.2(\mathrm{Ar})$, $130.5(\mathrm{Ar}), 130.9(\mathrm{Ar}), 132.2(\mathrm{Ar}), 149.8(\mathrm{Ar}), 153.9(\mathrm{Ar})$, 155.5 (Ar), 157.8 (OCO). Anal. Calcd for for $\mathrm{C}_{28} \mathrm{H}_{28} \mathrm{ClN}_{7} \mathrm{O}_{2}$. $3 \mathrm{HCl} \cdot 3 \mathrm{H}_{2} \mathrm{O}: \mathrm{C}, 48.50 ; \mathrm{H}, 5.38 ; \mathrm{N}, 14.14 ; \mathrm{Cl}, 20.45$. Found: C, 48.51; H, 5.36; N, 14.21; Cl, 20.25.

2-[2-(4-((2-Bromoethyl)carbamoyloxy)phenyl)-6-benzimi-

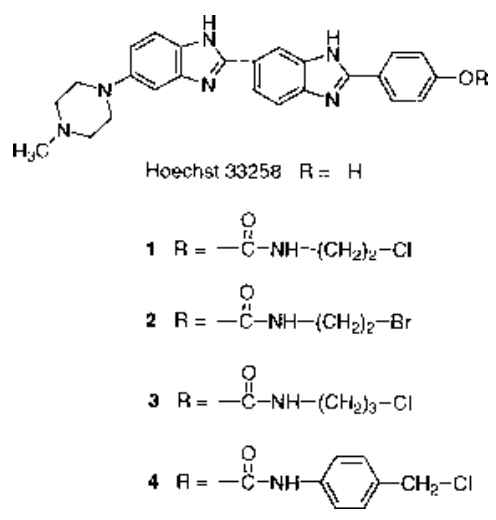

Fig. 1. Structure of Hoechst 33258 and Compounds $\mathbf{1}-\mathbf{4}$ 
dazolyl]-6-(1-methyl-4-piperazinyl)benzimidazole Trihydrochloride (2): Yield $=48 \%, \mathrm{mp}>300{ }^{\circ} \mathrm{C}$. ${ }^{1} \mathrm{H}-\mathrm{NMR}$ (DMSO$\left.d_{6}\right) \delta: 2.62\left(\mathrm{~s}, 3 \mathrm{H}, \mathrm{N}-\mathrm{CH}_{3}\right), 2.78\left(\mathrm{~m}, 4 \mathrm{H}, \mathrm{N}-\mathrm{CH}_{2}-\right), 3.36(\mathrm{~m}$, $\left.4 \mathrm{H}, \mathrm{N}-\mathrm{CH}_{2}-\right), 3.46\left(\mathrm{t}, 2 \mathrm{H}, \mathrm{N}-\mathrm{CH}_{2}-, J=5.8 \mathrm{~Hz}\right), 3.56(\mathrm{t}, 2 \mathrm{H}$, $\left.\mathrm{CH}_{2}-\mathrm{Br}, J=5.8 \mathrm{~Hz}\right), 6.95$ (d, $\left.1 \mathrm{H}, \mathrm{Ar}-\mathrm{H}, J=8.4 \mathrm{~Hz}\right), 7.11$ (s, $1 \mathrm{H}, \mathrm{Ar}-\mathrm{H}), 7.45$ (d, 1H, Ar-H, $J=9.0 \mathrm{~Hz}), 7.71$ (d, 1H, Ar-H, $J=9.2 \mathrm{~Hz}$ ), 7.82 (d, 2H, Ar-H, $J=8.2 \mathrm{~Hz}), 8.04$ (d, 1H, Ar-H, $J=8.7 \mathrm{~Hz}$ ), 8.19 (d, 2H, Ar-H, $J=9.4 \mathrm{~Hz}), 8.40$ (s, 1H, Ar-H). ${ }^{13} \mathrm{C}-\mathrm{NMR}\left(\mathrm{DMSO}-d_{6}\right) \delta: 34.2\left(\mathrm{CH}_{2}-\mathrm{Br}\right), 41.4\left(\mathrm{~N}-\mathrm{CH}_{3}\right), 48.4$ $\left(\mathrm{N}-\mathrm{CH}_{2}-\right), 53.5\left(\mathrm{~N}-\mathrm{CH}_{2}-\right), 102.5$ (Ar), 116.7 (Ar), 117.0 (Ar), 123.2 (Ar), 126.4 (Ar), 128.2 (Ar), 130.5 (Ar), 130.9 (Ar), 132.3 (Ar), 149.8 (Ar), 153.9 (Ar), 155.5 (Ar), 157.8 (OCO). Anal. Calcd for $\mathrm{C}_{28} \mathrm{H}_{28} \mathrm{BrN}_{7} \mathrm{O}_{2} \cdot 3 \mathrm{HCl} \cdot 3 \mathrm{H}_{2} \mathrm{O}: \mathrm{C}$, 45.58; H, 5.05; N, 13.29; Cl, 14.41. Found: C, 45.61; H, $5.08 ; \mathrm{N}, 13.31 ; \mathrm{Cl}, 14.35$.

2-[2-(4-((3-Chloropropyl)carbamoyloxy)phenyl)-6-benzimidazolyl]-6-(1-methyl-4-piperazinyl)benzimidazole Trihydrochloride (3): Yield $=52 \%, \quad \mathrm{mp}>300{ }^{\circ} \mathrm{C}$. ${ }^{1} \mathrm{H}-\mathrm{NMR}$ $\left(\mathrm{DMSO}-d_{6}\right) \delta: 1.83\left(\mathrm{~m}, 2 \mathrm{H},-\mathrm{CH}_{2}-\right), 2.60\left(\mathrm{~s}, 3 \mathrm{H}, \mathrm{N}-\mathrm{CH}_{3}\right)$, $2.80\left(\mathrm{~m}, 4 \mathrm{H}, \mathrm{N}-\mathrm{CH}_{2}-\right), 2.96\left(\mathrm{t}, 2 \mathrm{H}, \mathrm{N}-\mathrm{CH}_{2}-, J=6.6 \mathrm{~Hz}\right)$, 3.20 (t, $\left.2 \mathrm{H}, \mathrm{CH}_{2}-\mathrm{Cl}, \mathrm{J}=6.3 \mathrm{~Hz}\right), 3.36\left(\mathrm{~m}, 4 \mathrm{H}, \mathrm{N}-\mathrm{CH}_{2}-\right), 6.97$ (d, $1 \mathrm{H}, \mathrm{Ar}-\mathrm{H}, J=8.4 \mathrm{~Hz}), 7.05$ (s, 1H, Ar-H), 7.45 (d, 1H, Ar$\mathrm{H}, J=9.0 \mathrm{~Hz}$ ), 7.71 (d, 1H, Ar-H, $J=9.2 \mathrm{~Hz}), 7.86$ (d, 2H, Ar$\mathrm{H}, J=8.2 \mathrm{~Hz}$ ), 8.02 (d, 1H, Ar-H, $J=8.7 \mathrm{~Hz}), 8.19$ (d, 2H, Ar$\mathrm{H}, J=9.4 \mathrm{~Hz}$ ), $8.38(\mathrm{~s}, 1 \mathrm{H}, \mathrm{Ar}-\mathrm{H}) .{ }^{13} \mathrm{C}-\mathrm{NMR}$ (DMSO- $\left.d_{6}\right) \delta$ : $34.4\left(-\mathrm{CH}_{2}-\right), \quad 41.4 \quad\left(\mathrm{~N}-\mathrm{CH}_{3}\right), \quad 41.7 \quad\left(\mathrm{~N}-\mathrm{CH}_{2}-\right), \quad 42.1$ $\left(-\mathrm{CH}_{2}-\mathrm{Cl}\right), 53.5\left(\mathrm{~N}-\mathrm{CH}_{2}-\right), 102.5$ (Ar), 116.7 (Ar), 116.9 (Ar), 123.4 (Ar), 126.4 (Ar), 128.2 (Ar), 130.5 (Ar), 130.9 (Ar), 131.9 (Ar), 149.8 (Ar), 154.1 (Ar), 155.5 (Ar), 157.8 (OCO). Anal. Calcd for $\mathrm{C}_{29} \mathrm{H}_{30} \mathrm{ClN}_{7} \mathrm{O}_{2} \cdot 3 \mathrm{HCl} \cdot 3 \mathrm{H}_{2} \mathrm{O}: \mathrm{C}$, 49.23; H, 5.56; N, 13.86; Cl, 20.04. Found: C, 49.41; H, $5.48 ; \mathrm{N}, 13.81 ; \mathrm{Cl}, 20.10$.

2-[2-(4-((4-Chloromethylphenyl)carbamoyloxy)phenyl)-6benzimidazolyl]-6-(1-methyl-4-piperazinyl)benzimidazole Trihydrochloride (4): Yield $=44 \%, \mathrm{mp}>300{ }^{\circ} \mathrm{C}$. ${ }^{1} \mathrm{H}-\mathrm{NMR}$ $\left(\mathrm{DMSO}-d_{6}\right) \delta: 2.63\left(\mathrm{~s}, 3 \mathrm{H}, \mathrm{N}-\mathrm{CH}_{3}\right), 2.86\left(\mathrm{~m}, 4 \mathrm{H}, \mathrm{N}-\mathrm{CH}_{2}-\right.$ ), $3.36\left(\mathrm{~m}, 4 \mathrm{H}, \mathrm{N}-\mathrm{CH}_{2}-\right), 4.64\left(\mathrm{~s}, 2 \mathrm{H},-\mathrm{CH}_{2}-\mathrm{Cl}\right), 6.95(\mathrm{~d}, 1 \mathrm{H}$, $\mathrm{Ar}-\mathrm{H}, J=8.4 \mathrm{~Hz}), 7.05$ (s, 1H, Ar-H), 7.24 (d, 2H, Ar-H, $J=8.4 \mathrm{~Hz}$ ), 7.45 (d, 1H, Ar-H, $J=9.0 \mathrm{~Hz}), 7.60$ (d, 2H, Ar-H, $J=8.4 \mathrm{~Hz}$ ), 7.71 (d, 1H, Ar-H, $J=9.2 \mathrm{~Hz}), 7.82$ (d, 2H, Ar-H, $J=8.2 \mathrm{~Hz}$ ), 8.02 (d, 1H, Ar-H, $J=8.7 \mathrm{~Hz}), 8.17$ (d, 2H, Ar-H, $J=9.4 \mathrm{~Hz}), 8.30(\mathrm{~s}, 1 \mathrm{H}, \mathrm{Ar}-\mathrm{H}) .{ }^{13} \mathrm{C}-\mathrm{NMR}\left(\mathrm{DMSO}-d_{6}\right) \delta: 41.4$ $\left(\mathrm{N}-\mathrm{CH}_{3}\right), 50.5\left(-\mathrm{CH}_{2}-\mathrm{Cl}\right), 53.5\left(\mathrm{~N}-\mathrm{CH}_{2}-\right), 102.5(\mathrm{Ar}), 116.7$ (Ar), 116.9 (Ar), 120.6 (Ar), 123.1 (Ar), 126.4 (Ar), 128.2 (Ar), 129.0 (Ar), 130.3 (Ar), 130.9 (Ar), 132.2 (Ar), 133.6 (Ar), 138.2 (Ar), 149.7 (Ar), 153.9 (Ar), 155.5 (Ar), 157.8 (OCO). Anal. Calcd for $\mathrm{C}_{33} \mathrm{H}_{30} \mathrm{ClN}_{7} \mathrm{O}_{2} \cdot 3 \mathrm{HCl} \cdot 3 \mathrm{H}_{2} \mathrm{O}: \mathrm{C}$, 52.46; H, 5.20; N, 12.98; Cl, 18.77. Found: C, 52.51; H, $5.18 ; \mathrm{N}, 12.91 ; \mathrm{Cl}, 18.68$.

\section{PHARMACOLOGY}

Reagents and Materials Calf thymus DNA and 3-(4,5dimethylthiazole-2-yl)-2,5-diphenyltetrazolium bromide (MTT) were purchased from Sigma. Dulbecco's minimal essential medium (DMEM) and foetal bovine serum (FBS) used in cell culture were products of Gibco (U.S.A.). Glutamine, penicillin and streptomycin were obtained from Quality Biologicals Inc. (U.S.A.). $\left[{ }^{3} \mathrm{H}\right]$ Thymidine $(6.7 \mathrm{Ci} / \mathrm{mmol})$ was the product of NEN (U.S.A.).

Ultrafiltration Method A test compound $(100 \mu \mathrm{M})$ was mixed with calf thymus DNA $(0.5 \mathrm{~mm}$ as base pairs $)$ in 1.0 TB buffer (10 mm Tris $\cdot \mathrm{HC1}(\mathrm{pH})-1 \mathrm{~mm}$ EDTA containing $0.15 \mathrm{M} \mathrm{NaCl}$ ). The mixture was allowed to stand at room temperature overnight. The mixture was ultrafiltered using a ultrafree-MC centrifugal filter unit (PLCC NMWL 5000, Milipore) at $20^{\circ} \mathrm{C}$, then the content of the test compound in the filtrate was determined by UV-absorption measurement $\left(\right.$ Abs. $\left._{\text {DNA }+}\right)$ and this value was taken as the concentration of free compound ([comp $\left.]_{\mathrm{DNA}+}\right)$. The same procedure was carried out with a solution of the test compound in the absence of DNA as the control (Abs. DNA- $_{\text {- }}$ and [comp $]_{\mathrm{DNA}-}$, respectively). Measurements were made with a Unicam/Helios gamma UV-vis spectrophotometer at $\lambda_{\max }=341 \mathrm{~nm}$ for compounds $\mathbf{1}-\mathbf{4}$ and Hoechst 33258 (Table 1). Results are the means of three independent experiments. The DNA-binding ability of the test compound was defined by the following equation:

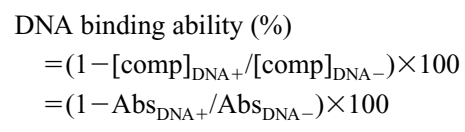

MCF-7 Cultures Breast cancer MCF-7 cells were maintained in DMEM supplemented with $10 \%$ FBS, $50 \mu \mathrm{g} / \mathrm{ml}$ penicillin, $50 \mu \mathrm{g} / \mathrm{ml}$ streptomycin at $37^{\circ} \mathrm{C}$ in a $5 \% \mathrm{CO}_{2}$ incubator. Cells were cultured in Costar flasks and subconfluent cells were detached with $0.05 \%$ trypsin, $0.02 \%$ EDTA in calcium-free phosphate-buffered saline, counted in hemocytometers and inoculated at $5 \times 10^{5}$ cells per well of six-well plates (Nunc, Wiesbaden, Germany) in $2 \mathrm{ml}$ of growth medium. Cells reached about $80 \%$ of confluence at day 3 after inoculation and in most cases such cells were used for the assays.

Cytotoxic Assay To examine the effect of studied drugs on MCF-7 proliferation, the cells were seeded in 24 well tissue culture dishes at $1 \times 10^{5}$ cells/well with $1 \mathrm{ml}$ of growth medium. After $48 \mathrm{~h}\left(1.8 \pm 0.1 \times 10^{5}\right.$ cells/well $)$ plates were incubated with varying concentrations of compounds $1-\mathbf{4}$ and Hoechst 33258 and $0.5 \mu \mathrm{Ci}$ of $\left[{ }^{3} \mathrm{H}\right]$ thymidine for $24 \mathrm{~h}$ at $37^{\circ} \mathrm{C}$. Cells were rinsed 3 times with PBS, solubilized with $1 \mathrm{ml}$ of $0.1 \mathrm{M}$ sodium hydroxide containing $1 \%$ sodium dodecyl sulfate (SDS), scintillation fluid $(9 \mathrm{ml})$ was added and radioactivity incorporation into DNA was measured in scintillation counter.

Cell Viability Assay The assay was performed according to the method of Carmichael using 3-(4,5-dimethylthiazole-2-yl)-2,5-diphenyltetrazolium bromide (MTT). ${ }^{11)}$ Confluent cells, cultured for $48 \mathrm{~h}$ with various concentrations of studied compounds in 6-well plates were washed three times with PBS and then incubated for $4 \mathrm{~h}$ in $1 \mathrm{ml}$ of MTT solution $(0.5 \mathrm{mg} / \mathrm{ml}$ of PBS $)$ at $37^{\circ} \mathrm{C}$ in $5 \% \mathrm{CO}_{2}$ in an incubator. The medium was removed and $1 \mathrm{ml}$ of $0.1 \mathrm{M} \mathrm{HCl}$ in absolute isopropanol was added to attached cells. Absorbance of converted dye in living cells was measured at a wavelength of $570 \mathrm{~nm}$. Cell viability of breast cancer MCF-7 cells cultured in the presence of ligands was calculated as a per cent of control cells.

Statistical Analysis In all experiments, the mean values for six independent experiments \pm standard deviations (S.D.) were calculated, unless otherwise indicated. The results were submitted to statistical analysis using Students $t$-test, accepting $p<0.05$, as significant. 
Table 1. DNA-Binding Abilities of Compounds $\mathbf{1}-\mathbf{4}$ and Hoechst 33258 Determined by Ultrafiltration Assay Using Calf Thymus DNA

\begin{tabular}{|c|c|c|c|c|c|c|}
\hline \multirow[b]{2}{*}{ Comp. } & \multirow[b]{2}{*}{ Abs. DNA $(-)^{a)}$} & \multirow[b]{2}{*}{ Abs. $\operatorname{DNA}(+)^{a)}$} & \multirow{2}{*}{$\begin{array}{l}\text { DNA-binding } \\
\text { ability }^{b)}(\%)\end{array}$} & \multicolumn{3}{|c|}{ Scatchard analyses } \\
\hline & & & & $\begin{array}{c}\text { Binding constant }\left(K_{\mathrm{a}}\right) \\
\left(10^{3} \mathrm{M}^{-1}\right)\end{array}$ & $\begin{array}{l}\text { Binding sites }(n) \\
\quad(\text { per bp) }\end{array}$ & $\begin{array}{l}\text { Correlation } \\
\text { coefficient }(R)\end{array}$ \\
\hline Hoechst 33258 & 0.469 & 0.143 & 69.5 & 7.2 & 0.4 & 0.76 \\
\hline 1 & 0.480 & 0.185 & 61.4 & 5.5 & 0.4 & 0.81 \\
\hline 2 & 0.472 & 0.160 & 66.1 & 6.6 & 0.4 & 0.77 \\
\hline 3 & 0.477 & 0.130 & 72.7 & 7.6 & 0.5 & 0.79 \\
\hline 4 & 0.498 & 0.116 & 76.7 & 8.9 & 0.5 & 0.80 \\
\hline
\end{tabular}

a) The UV-absorption was measured at $\lambda_{\max }=341 \mathrm{~nm}$ after 5 dilution with 1.0 buffer. $\quad$ b) DNA binding ability $(\%)=\left(1-\mathrm{Abs}_{\mathrm{DNA}+} / \mathrm{Abs}_{\mathrm{DNA}-}\right) \times 100$.

\section{RESULTS AND DISCUSSION}

In this study we describe the synthesis of Hoechst 33258 derivatives appropriately modified with linkers that allow covalent attachment to DNA sequences. These new compounds 1-4 were prepared in good yields by addition of chloroethyl, bromoethyl, chloropropyl or 4-(chloromethyl)phenyl isocyanates to Hoechst 33258. The phenolate group attacked the isocyanates under basic conditions, leaving intact the benzimidazole rings even under excess of isocyanate reagent. The chemical structures of the synthesized compounds were confirmed by means their elemental analysis, ${ }^{1} \mathrm{H}-$ and ${ }^{13} \mathrm{C}-$ NMR.

It is widely accepted that Hoechst 33258 derivatives are minor groove binders. ${ }^{3,4)}$ Although various factors are known to be responsible for minor groove binding, their importance can vary from ligand to ligand and no simple rules have emerged yet. Moreover, the dependence of binding specificity of particular ligands on length, sequence composition and flanking regions of the AT tract is widely unexplored. The DNA-binding ability of $\mathbf{1}-\mathbf{4}$ and Hoechst 33258 was evaluated by the ultrafiltration method using calf thymus DNA. ${ }^{12-14)}$ The binding constants $K_{\mathrm{a}}$ and number of sites per nucleotide $n$ were estimated from Scatchard plots using the classical Scatchard equation for independent binding sites without cooperativity. ${ }^{15)}$ The ultrafiltration assay using calf thymus DNA showed that the DNA-binding ability of compounds $1-4$ was similar to that of Hoechst 33258 (Table 1). DNA-binding studies indicated that 4 exhibits the highest affinity for DNA. The order of DNA-binding under the ultrafiltration assay conditions of the test compounds is $\mathbf{4}>$ $\mathbf{3}>$ Hoechst $33258>\mathbf{1}>\mathbf{2}$. As can be seen from the Table 1, the binding constant $\left(K_{\mathrm{a}}\right)$ for compounds $\mathbf{1}-\mathbf{4}$ varies from $8.9 \times 10^{3} \mathrm{M}^{-1}$ for 4 to $5.5 \times 10^{3} \mathrm{M}^{-1}$ for 2 . The binding site size remains essentially constant, suggesting similar binding contacts across the series.

We studied the effect of carbamates 1-4 and Hoechst 33258 on DNA synthesis in cultured breast cancer MCF-7 cells (Fig. 2). The $\mathrm{IC}_{50}$ of compounds $\mathbf{1}, \mathbf{2}, \mathbf{3}$ and $\mathbf{4}$ for DNA synthesis was found to be $45,35,25$ and $20 \mu$ M respectively, suggesting higher cytotoxic potency compared to Hoechst $53228\left(\mathrm{IC}_{50}=55 \mu \mathrm{M}\right)$. Cell viability was measured by the method of Carmichael using tetrazolium salt. ${ }^{11)}$ The carbamate 1 appears to have only marginally elevated cytotoxicity with respect to the parent compound, Hoechst 33258 (Table 2 ). The compound $\mathbf{2}$, a bromine derivative, demonstrated somewhat greater cytotoxicity than $\mathbf{1}$, and like $\mathbf{3}$ displayed a trend to increased cytotoxicity compared with the parent

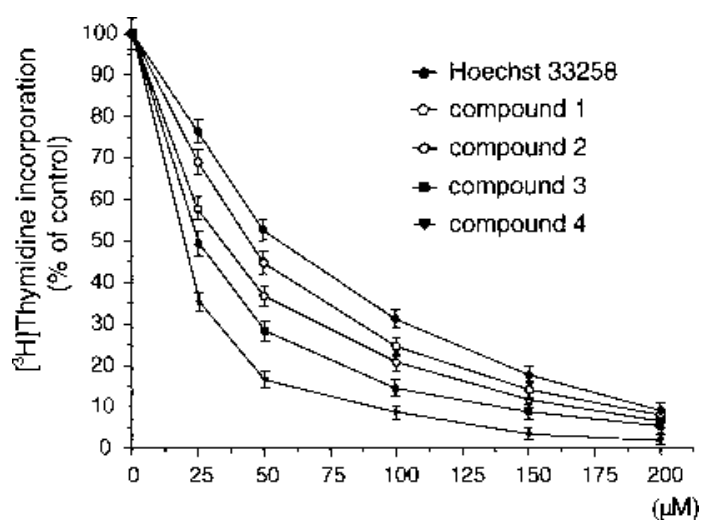

Fig. 2. Cytotoxic Effects of Compounds 1-4 and Hoechst 33258 on Cultured Breast Cancer MCF-7 Cells as Measured by Inhibition of [ $\left.{ }^{3} \mathrm{H}\right]$ Thymidine Incorporation into DNA

Table 2. Viability of MCF-7 Cells Treated for $48 \mathrm{~h}$ with Different Concentrations of Compounds $\mathbf{1}-\mathbf{4}$ and Hoechst 33258

\begin{tabular}{cccccc}
\hline \hline \multirow{2}{*}{$\begin{array}{c}\text { Concentration } \\
(\mu \mathrm{M})\end{array}$} & \multicolumn{5}{c}{ Viability of cells (\% of control) } \\
\cline { 2 - 6 } & Hoechst 33258 & $\mathbf{1}$ & $\mathbf{2}$ & $\mathbf{3}$ & $\mathbf{4}$ \\
\hline 0 & 100 & 100 & 100 & 100 & 100 \\
10 & $83 \pm 2$ & $79 \pm 2$ & $72 \pm 2$ & $68 \pm 2$ & $61 \pm 2$ \\
25 & $75 \pm 2$ & $73 \pm 2$ & $64 \pm 2$ & $60 \pm 2$ & $53 \pm 2$ \\
50 & $67 \pm 2$ & $64 \pm 2$ & $56 \pm 2$ & $52 \pm 2$ & $46 \pm 2$ \\
75 & $56 \pm 2$ & $51 \pm 2$ & $46 \pm 2$ & $44 \pm 2$ & $35 \pm 2$ \\
100 & $49 \pm 2$ & $47 \pm 2$ & $37 \pm 2$ & $33 \pm 2$ & $24 \pm 2$ \\
\hline
\end{tabular}

compound (Table 2). The carbamate $\mathbf{4}$ demonstrated a significantly increased cytotoxicity with respect to Hoechst 33258 . As can be seen 4 at the concentration of $75 \mu \mathrm{M}$ produced about a $65 \%$ reduction in cell viability in breast cancer MCF7 cells. These data show that in broad terms the cytotoxic potency of 1-4 in cultured breast cancer MCF-7 cells increases in accord with their increases in DNA affinity, as shown by the binding constant values (Table 1). This activity may be related to the ability of these compounds to inhibit transcription, especially at AT-rich sequences. The parent compound Hoechst 33258 has been reported to act at the cellular level by poisoning the enzymes DNA topoisomerases I, or possibly by stabilizing the cleavable complexes formed by DNA and DNA topoisomerases I and II, which would result in cytotoxic DNA strand cleavage. ${ }^{16-18)}$ This suggests that DNA-binding may be implicated in the cytotoxicity of $\mathbf{1}-\mathbf{4}$, possibly by inhibiting interactions between cellular proteins and their DNA targets. Further studies of structure-activity 
relationships in this series, and preparation of related compounds are now in progress.

\section{REFERENCES}

1) Reddy B. S. P., Sharma S. K., Lown J. W., Curr. Med. Chem., 8, 475508 (2001).

2) Moon J. H., Kim S. K., Sehistedt U., Rodger A., Norden B., Biopolymers, 38, 593-606 (1996).

3) Neidle S., Biopolymers, 44, 105-121 (1997).

4) Spink N., Brown D. G., Skelly J. V., Neidle S., Nucleic Acids Res., 22, 1607-1612 (1994).

5) Bailly C., Colson P., Henichart J. P., Houssier C., Nucleic Acids Res., 21, 3705-3711 (1993).

6) Fairley T. A., Tidwell R. R., Donkor A., Naiman N. A., Ohemeng K. A., Bentley J. A., Cory M., J. Med. Chem., 36, 1746-1753 (1993).

7) Mann J., Baron A., Opoku-Boahen Y., Johansson E., Parkinson G., Kelland L. R., Neidle S. A., J. Med. Chem., 44, 138-144 (2001).

8) Denny W. A., Curr. Med. Chem., 8, 533-544 (2001).
9) Soderlind K. J., Gorodetsky B., Singh A. K., Bachur N. R., Miller G. G., Lown J. W., Anti-Cancer Des., 14, 19-36 (1999).

10) Kraut E. T., Fleming M., Segal J., Neidhart N., Behrens B. C., MacDonald J., Invest. New Drugs, 9, 95-96 (1991).

11) Carmichael J., Degraff W., Gazdar A., Minna J., Mitchell J., Cancer Res., 47, 936-942 (1987).

12) Shichita M., Shimazawa R., Nakajima O., Mizoguchi H., Hashimoto Y., Iwasaki S., Biol. Pharm. Bull., 18, 637-639 (1995).

13) Fukutomi R., Kagechika H., Hashimoto Y., Shudo K., Chem. Pharm. Bull., 44, 1983-1985 (1996).

14) Bielawski K., Wołczyński S., Bielawska A., Biol. Pharm. Bull., 24, $704-706$ (2001)

15) Scatchard G., Ann. N.Y. Acad. Sci., 51, 660-672 (1949).

16) Tolner B., Hartley J. A., Hochhauser D., Mol. Pharmacol., 59, 699706 (2001).

17) Kim J. S., Sun Q., Yu C., Liu A., Liu L., LaVoie E., Bioorg. Med. Chem., 6, 163-172 (1998).

18) Zhang X., Chen J., Davis B., Kiechle F., Arch. Pathol. Lab. Med., 123, 921-927 (1999). 